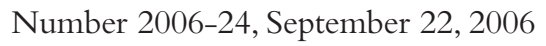

\title{
Oil Prices and the U.S. Trade Deficit
}

With the price of oil in world energy markets having nearly quadrupled over the last four years, it is little surprise that U.S. import prices have soared. One concern about these higher import prices relates to their implications for the U.S. trade balance, which turned to a deficit in 1992 and has been deteriorating ever since.

This Economic Letter explores the relation between the surge in oil prices and the trade deficit by first reviewing data on U.S. international trade in goods and services. It then discusses a recent study that examines how the U.S. trade deficit might evolve in response to higher oil prices. Finally, it considers a model that can help explain why, surprisingly, the volume of U.S. petroleum imports has remained essentially constant, despite the remarkable increase in their cost and what that implies for the trade deficit.

\section{Has the increase in oil prices}

\section{affected the U.S. trade deficit?}

Figure 1 plots monthly data from January 2002 to July 2006 for both the overall trade balance and the petroleum-related trade balance; the latter includes imports and exports of crude oil, fuel oil, liquefied petroleum gases, and other petroleum products. It shows that the overall monthly trade deficit went from $\$ 30$ billion to $\$ 68$ billion, and the petroleum-related trade deficit went from $\$ 6$ billion to $\$ 26$ billion. These numbers imply that higher oil prices and the resulting higher cost of petroleum imports have accounted for over 50\% of the deterioration in the overall U.S. trade deficit during this period. Indeed, looking at only the last two years, from August 2004 to July 2006, the data are more striking. The overall trade deficit grew from $\$ 54$ billion to $\$ 68$ billion and the petroleumrelated trade deficit rose from $\$ 14$ billion to $\$ 26$ billion, indicating that the deterioration in the petroleum-related trade deficit accounts for 80\% of the worsening in the overall trade deficit.

\section{How will higher oil prices}

\section{affect the U.S. trade deficit?}

If oil prices persist at higher levels, what will happen to the U.S. trade deficit? Will it continue to deteriorate, or will it level off over time, or even revert to a balanced position? These questions are partic-
Figure 1

U.S. international trade balance in goods and services

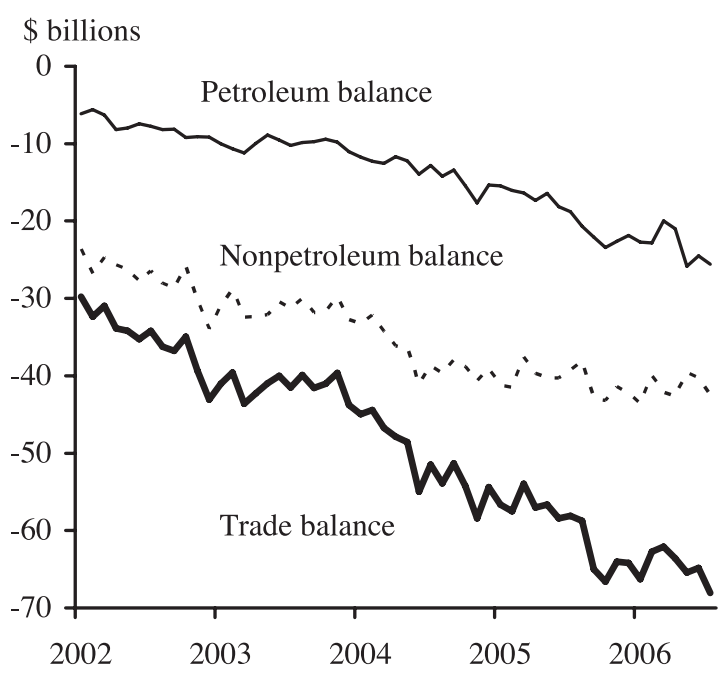

ularly pertinent because oil futures markets indicate that oil prices may well remain at their relatively high current levels for the foreseeable future.

To tackle these questions, Rebucci and Spatafora (2006) examine how an advanced oil-importing economy like the U.S. adjusts to a permanent increase in the price of oil. As one would expect, they find that, as the price of oil rises, the overall trade deficit increases noticeably relative to its baseline level. In their analysis, the adjustment process works through the effects of relative price changes on the nonpetroleum trade deficit. Specifically, as oil imports become more expensive, households and businesses have fewer resources to spend on other goods and services, which leads to a contraction in domestic nonpetroleum demand for consumption and investment. This contraction, in turn, leads to a decline in the terms-of-trade, which is the relative price of domestic tradables in terms of foreign tradables. In particular, lower domestic demand for nonpetroleum products leads to lower domestic demand for domestic tradables, which is compensated only in part by higher foreign demand coming from oil-exporting countries, which is generated by their higher oil revenues. This effect is related to "home bias," as domestic tradables normally represent a disproportionately higher share of domestic demand than they do of foreign 
demand. As a result, a contraction in domestic nonpetroleum demand generates a lower overall demand for domestic tradables and, correspondingly, an excess of supply of these goods, leading therefore to a decline in their relative price. As domestic tradables become more competitive, export sales increase and the nonpetroleum trade balance improves. In turn, this improvement helps the overall trade deficit, so that, eventually, it returns to its baseline level.

How has this adjustment process played out in the U.S. so far? During the last two years, the nonpetroleum trade deficit has not improved but has actually remained constant, at $\$ 44$ billion. This suggests that the adjustment process in the U.S. overall trade deficit is occurring quite slowly. How long, then, can the adjustment process take? The answer depends, in part, on the persistence of the oil price increase: The longer oil prices stay at high levels, the longer it will take for the trade deficit to adjust.

As Rebucci and Spatafora point out, the answer also depends on other factors, two of which I will highlight here. The first factor is the monetary policy responses of oil-importing countries. Monetary policy, of course, affects interest rates, which, in turn, affect domestic aggregate demand and economic growth in oil-importing countries, ultimately influencing their demand for imports and, therefore, the evolution of their overall trade deficit. When higher oil prices start to raise not only headline inflation but also core inflationthat is, the price measure that excludes food and energy - the central bank usually tightens monetary policy to offset the inflationary pressure. The resulting increase in interest rates dampens domestic aggregate demand even further, leading to slower economic growth, a decline in the demand for imports, and a faster improvement in the overall trade deficit.

In theory, the increase in interest rates can also induce an offsetting effect on the trade deficit by appreciating the domestic currency. The currency appreciation, by making domestic goods relatively more expensive than imported goods, can lead to a decline in exports, an increase in imports, and a deterioration in the overall trade deficit. In reality, however, this effect is likely to be smaller than the one that works through the reduction in the demand for imports. In fact, empirical evidence shows that the degree of pass-through of exchange rate movements to domestic import prices is quite limited, and that the demand for imports and exports tends to be rather unresponsive to relative price changes. As a result, the effect that works through the demand for imports is likely to dominate, so that an increase in the domestic interest rate leads to a faster improvement in the overall trade balance.

How much tightening the central bank does may depend on how well-anchored the public's inflation expectations are-in other words, on how firmly the public expects inflation to stay in the vicinity of price stability in the future. For example, in the U.S., inflation expectations appear to be pretty well-anchored, and, as a result, higher oil prices have had only a limited impact on core inflation; therefore, with well-anchored expectations, the Fed has not had to raise interest rates aggressively. Rebucci and Spatafora conclude that this factor might have helped delay the adjustment of trade deficits in the U.S. The speed of the adjustment can also be affected by how strongly the central bank responds to any increase in inflation expectations and core inflation.

The second factor is the extent to which oilexporting countries spend or save their additional revenues from higher oil prices. In fact, oilexporting countries have been quite cautious about increasing their spending in response to the windfall generated by larger oil revenues. One consequence of the resulting increase in saving by these economies has been a larger global supply of funds, helping to keep global interest rates at lower levels. Rebucci and Spatafora suggest that unusually low global interest rates might have limited the contraction in demand, thereby facilitating the persistence of trade deficits. Obstfeld and Rogoff (1995) argue that this factor was also at work after the oil-price increase of the early 1970s; at that time, oil-exporting countries were unable to raise their spending in line with the increase in oil revenues. As spending in oil-exporting countries rose by less than it fell in oil-importing countries, the amount of global saving increased and helped push global interest rates down.

\section{Why have U.S. oil imports not declined as oil prices have increased?}

In the U.S., one additional factor that has hindered the adjustment of the trade deficit is that the volume of oil imports has remained essentially constant. As shown in Figure 2, two measures of oil imports - the quantity of crude oil imports and the amount of real petroleum-related importshave not declined in response to the oil price increases that began in 2002. As a result, increases in both nominal expenditures for petroleum im- 


\section{Figure 2}

\section{Measures of oil imports}

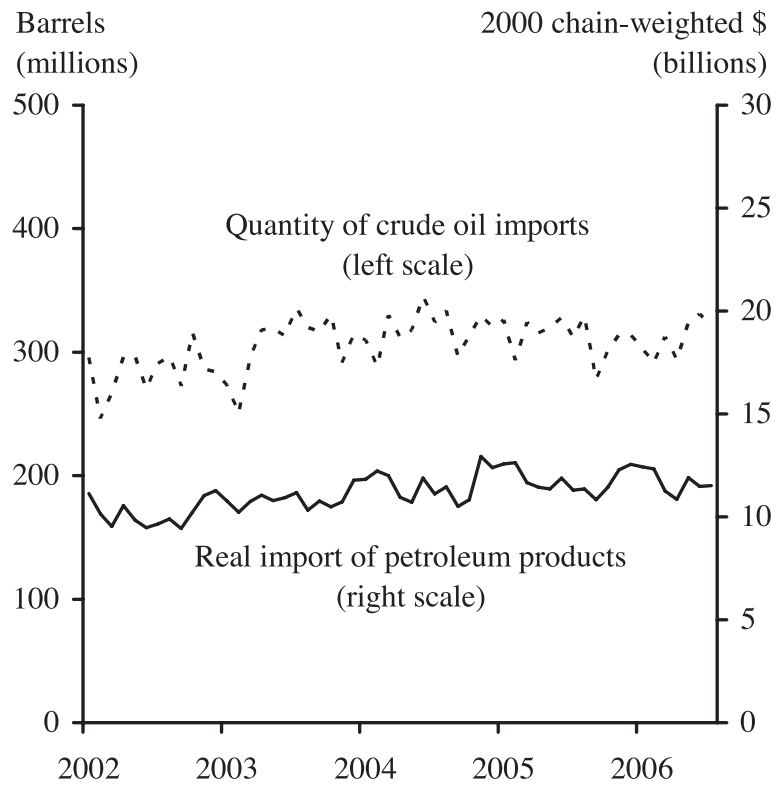

ports and the petroleum-related trade deficit have tracked increases in petroleum import prices quite closely. Though this finding may seem surprising, Atkeson and Kehoe (1999) note that this pattern is fairly well known among energy economists, who have observed that, in the short run, the use of energy resources, such as oil, is fairly unresponsive to price movements.

Atkeson and Kehoe construct a model that captures this feature of the data. The mechanism underlying their model helps explain why oil imports have not declined and why the U.S. trade deficit has not adjusted as oil prices have soared.

In their model oil enters as an energy input, which is combined with the stock of existing capital goods to produce consumption goods. These capital goods are designed to use energy in fixed proportions; in other words, they require a fixed complement of energy to operate. Therefore, firms cannot adjust their energy consumption in response to higher energy prices in the short run.

In the long run, however, matters are quite different. With persistently higher energy prices, businesses tend to invest in new types of capital goods that use lower proportions of energy. As a result, energy use ultimately is quite responsive to higher energy prices, as more energy-efficient capital goods replace less energy-efficient ones over time.

\section{Conclusions}

Oil prices have almost quadrupled since the beginning of 2002. For an oil-importing country like the U.S., this has substantially increased the cost of petroleum imports. International trade data suggest that this increase has exacerbated the deterioration of the U.S. trade deficit, especially since the second half of 2004. One factor can explain this evolution: The real volume of U.S. petroleum imports has remained essentially constant. One explanation for why the demand for petroleum imports has not declined in response to higher prices comes from a model in which firms are fairly limited in their ability to adjust their use of energy sources, such as oil, in the short term.

Of course, the mechanism underlying this model may imply that it could take a while for the U.S. trade deficit to adjust in response to persistently higher oil prices, as businesses need time to install new, less energy-intensive equipment. However, one positive and important implication is that eventually the U.S. economy will become more energy-efficient, which, in turn, would help contain the cost of oil imports and increase the economy's flexibility in absorbing future oil price increases.

\section{Michele Cavallo Economist}

\section{References}

[URL accessed September 2006.]

Atkeson, Andrew, and Patrick J. Kehoe. 1999. "Models of Energy Use: Putty-Putty versus Putty-Clay." American Economic Review 89(4) (September), pp. 1028-1043.

Obstfeld, Maurice, and Kenneth S. Rogoff. 1995. Foundations of International Macroeconomics. Cambridge, MA: MIT Press.

Rebucci, Alessandro, and Nikola Spatafora. 2006. "Oil Prices and Global Imbalances." In IMF World Economic Outlook (April 2006), pp. 71-96. Washington, DC: International Monetary Fund. http://www.imf.org/external/pubs/ft/weo/2006/ 01/pdf/c2.pdf 


\section{P.O. Box 7702}

San Francisco, CA 94120

Address Service Requested

Postal Savings in Japan and Mortgage Markets in the U.S.

External Imbalances and Adjustment in the Pacific Basin

Enhancing Fed Credibility

What Is the Federal Reserve Banks' Imputed Cost of Equity Capital?

Security Analysts and Regulatory Reform

Job Matching: Evidence from the Beveridge Curve

Prospects for the Economy

Bank Diversification, Economic Diversification?

Central Bank Capital, Financial Strength, and the Bank of Japan

Monetary Policy in a Global Environment

International Financial Integration and the Current Account Balance

Residential Investment over the Real Estate Cycle

A Monetary Policymaker's Passage to India

Labor Markets and the Macroeconomy: Conference Summary

Property Debt Burdens

Performance Divergence of Large and Small Credit Unions

Would an Inflation Target Help Anchor U.S. Inflation Expectations?

New Uses for New Macro Derivatives

Inflation Targets and Inflation Expectations: Some Evidence...

The Exchange Rate-Consumer Price Puzzle
Cargill/Scott

Glick/Spiegel

Yellen

Barnes/Lopez

Marquez

Valletta/Hodges

Yellen

Strahan

Cargill

Yellen

Cavallo

Krainer

Yellen

Dennis/Williams

Doms/Motika

Wilcox

Swanson

Wolfers

Trehan/Tjosvold

Valderrama

Opinions expressed in the Economic Letter do not necessarily reflect the views of the management of the Federal Reserve Bank of San Francisco or of the Board of Governors of the Federal Reserve System. This publication is edited by Judith Goff, with the assistance of Anita Todd. Permission to reprint portions of articles or whole articles must be obtained in writing. Permission to photocopy is unrestricted. Please send editorial comments and requests for subscriptions, back copies, address changes, and reprint permission to: Public Information Department, Federal Reserve Bank of San Francisco, P.O. Box 7702, San Francisco, CA 94120, phone (415) 974-2163, fax (415) 974-3341, e-mail sf.pubs@sf.frb.org. The Economic Letter and other publications and information are available on our website, http://www.frbsf.org. 